\title{
Relationship of Spiritual Well-Being and Attitudes of Tolerance for Youth Raja Oloan Tumanggor and Heni Mularsih
}

\author{
Rajat $^{1}$, henim ${ }^{2}$ \\ \{rajat@fpsi.untar.ac.id ${ }^{1}$, henim@mku.untar.ac.id $\left.{ }^{2}\right\}$ \\ Faculty of Psychology, Universitas Tarumanagara Jakarta
}

\begin{abstract}
The intolerant attitude that is increasingly prevalent lately also involves teenagers. Various intolerant actions for groups that have different cultural, religious and ethnic backgrounds are truly alarming. To increase religious tolerance for teenagers, it is necessary to look at the spiritual aspects of well-being. This study wants to analyze the relationship between spiritual well-being and religious tolerance for adolescents. Spiritual well-being is a life affirmation in relation to oneself, community, environment and God. The study aims to determine the relationship between spiritual well-being and tolerance. The research subjects were teenagers who were still studying in junior and senior high schools who were collected through convenience sampling. The incoming data is processed and analyzed critically. The results show that spiritual well-being is related to tolerance $(r=0.475 * *, p=0.000<0.01)$. The higher the level of spiritual wellbeing, the better tolerance of adolescents.
\end{abstract}

Keywords: spiritual well-being, tolerance attitudes, youth.

\section{Introduction}

At the beginning of 2018 there were several incidents of attacks on several religious leaders in Indonesia, such as K.H. Umar Basri on January 27 in Bandung Regency, Ustadz Prawoto on February 1 in Bandung and Father Karl Edmund Prier, SJ on February 11 in Sleman. These various acts of violence may be attributed to situations of intolerance in society, especially intolerance among religious followers. According to the Declaration on the Elimination of All Forms of Intolerance and Discrimination based on Religion or Belief, intolerance is the differentiation, neglect, prohibition or prioritization based on religion or belief whose purpose is to eliminate or reduce the recognition, enjoyment or implementation of human rights (Gerintya , 2018)[1]. According to the 2016 Equivalent Institute records there are 208 violations of freedom of religion/belief with 270 forms of action. There were 130 actions carried out by non-state actors with the highest number of perpetrators as many as 42 groups. In 2017 there were 155 incidents of violations of freedom of religion/belief with 201 forms of action. A total of 126 actions carried out by non-state actors with the highest perpetrators were citizens, 28 actions. In several cities in Indonesia there are several cases related to the practice of intolerance that starts from the dissemination of information that is wrong and hatred for a belief, limitation of human rights to certain beliefs, and omission of intolerant groups. This intolerance practice often involves teenagers. Teenagers are a group of 
people who are struggling to find their identity and at the same time become a determining group in the progress of future generations. A nation will advance if its adolescents receive adequate assistance. However, in the current situation, adolescents become intolerant acts due to the influence of their environment. Cases of intolerance are a serious problem and can have negative consequences for adolescents if they are not addressed immediately (Supriyanto \& Wahyudi, 2017)[2].

Many factors make teenagers fall into intolerant actions in society. Social media makes teenagers easily obtain information from radical understandings. It is not uncommon for teenagers to be an easy target for extreme organizations that spread radical ideologies that threaten pluralism in Indonesia. Information about radical understanding easily reaches teenagers. In addition, adolescents who lack adequate spiritual guidance from religious institutions and their families will be increasingly vulnerable to various negative influences including intolerant attitudes.

To fortify teenagers from an intolerant attitude, it is necessary to pay attention to the spiritual aspects of their well-being. Spiritual well-being is life affirmation in relation to God, self, community and environment (Fisher, 2010)[3]. Spiritual Well-Being is an indication of a person's quality of life in the spiritual dimension or an indication of his spiritual health (Bufford, Paloutzian \& Ellison, 1991)[4]. Does spiritual well-being play a role in tolerance among teenagers? This research will prove the role of spiritual well-being towards tolerance for adolescents.

Already many researchers in the field of psychology review the phenomena/symptoms that live in society, especially those who experience intolerant actions. However, research generally revolves around extracting the causes of intolerant actions and what efforts must be made to overcome them. Research based on the relationship of spiritual well-being and tolerance for adolescents is still quite rare. So this study seeks to fill this gap. Research seeks to examine the relationship of spiritual well-being with tolerance for adolescents.

\section{Theoretical Review}

According to J.W. Fisher (2010) Spiritual Well-Being is the affirmation of life in relating to God, oneself, community and environment together. This relationship is then developed in four interconnected domains. The four domains include the first, the personal domain, where a person relates to himself concerning the meaning, goals and values in life. This awareness becomes the decisive power of the human spirit in seeking self-identity. Second, the communal domain appears in the quality and depth of interpersonal relations between oneself and others, relating to morality, culture and religion. This relationship is expressed in love, forgiveness, trust, hope and faith. Third, the environmental domain concerns physical and biological maintenance, ownership and awe and the idea of unity with the environment. Fourth, the transcendental domain (God) involves self-relationship with something that goes through human aspects, such as concern for cosmic power and transcendent reality or God (Fisher \& Ng, 2017)[5].

Tolerance comes from the Latin word tolerare which means to let. In English tolerance means the attitude of allowing, acknowledging and respecting the beliefs of others without the need for approval. So tolerance is an airy attitude towards the principles of others. This does not mean sacrificing the principle he adheres to, but remains strong in the principle reflected in his solid attitude to follow his beliefs. According to Khisbiyah (2007)[6] tolerance is the 
ability to hold things that are not approved in order to build better social relations. Tolerance presupposes acceptance and respect for the views, beliefs, values of other groups that are different from us. While intolerance is the unwillingness to respect and accept differences.

According to Galtung \& Fischer (2013)[7] tolerance has a variety of characters, namely peace, respect for differences and individuals and awareness. This aspect of peace is reflected in the form of caring, fear and love for others. While aspects of respecting differences and individuals can be realized through mutual respect for one another, respect for differences in others, and self respect. Then the aspect of consciousness will be realized through respecting the goodness of others, being open, comfortable in life and comfortable with others.

From the description above tolerance can be understood as an attitude of willingness to accept diversity and trust that is believed by other parties/groups. This recognition is not only in the degree of equality in the state and society, but also in differences in how to live and do worship (Bahari, 2010)[8]. The attitude of tolerance is a person's awareness to respect, and to allow the establishment, views, beliefs, and provide space for the implementation of the habits, behaviors, and practices of other religious people that are different or contrary to their own establishment in order to build a shared life and better social relationship.

With tolerance, the unity of the nation will be preserved. Development can be pursued and continued, so that gaps can be minimized. The attitude of tolerance is based on the principle of good brotherhood, working together to face the enemy and defend the suffering

Teenagers are a group of people who experience a transition period from childhood and adulthood between the ages of 11 and 21 years. Adolescence begins with rapid physical changes, dramatic weight gain and height, changes in body shape, and development of sexual characteristics such as enlargement of breasts, development of the waist and mustache and the depth of the sound. In this development, attainment of independence and accentuation of identity is obtained, because thoughts are increasingly logical, abstract and idealistic and spend a lot of time outside the family. So in adolescence, changes occur biologically, positively and socially emotionally (Santrock, 2003)[9]. Adolescence is a transition period from childhood to adulthood which experiences the development of all aspects and functions to enter adulthood (Rumini \& Sundari, 2004)[10].

\section{Method}

The population of this study was 112 adolescents from the ages of 14 to 21 years at junior and high school $\mathrm{X}$ in Jakarta. The sampling technique was convenience sampling technique. The method of data collection is done by distributing questionnaires. There are two kinds of scales namely Spiritual Well-Being Scale and Tolerance Scale. The scale of spiritual well-being used is the result of adaptation from Spiritual Health and Life-Orientation Measure (SHALOM) by Fisher (2010). This scale consists of 20 items consisting of four dimensions, namely personal dimensions (5 items), communal (5 items), environment (5 items) and transcendental or God (5 items). After this measuring instrument is tested to 80 people, all items are valid and no items must be omitted and the reliability of 0.895 is obtained, meaning that the measure of spiritual well-being has fulfilled the validity and reliability.

While the scale of the attitude of religious tolerance is the result of adaptation of the scale of tolerance attitudes compiled by Supriyanto \& Wahyudi (2017) based on the research of Galtung \& Fischer (2013) regarding the concept of peace and the theory of character tolerance from Tillman (2004)[11]. This scale of tolerance consists of 39 items and is arranged 
based on three dimensions, namely first: dimensions of peace (12 items), second: respect for differences and individuals (12 items), third: awareness (15 items). Peace has a tolerance indicator in the form of: caring, fear, and love. Respect for differences has a tolerance indicator in the form of: respecting each other, respecting others' differences, and respecting oneself. While awareness has indicators such as: respecting the goodness of others, being open, receptive, comfort in life, and comfort with others. The measuring instrument was tested on 80 subjects to determine its validity and reliability. After being tested, 31 valid items were obtained and 8 were invalid. The reliability of the measuring instrument is 0.852 , meaning that the measuring instrument of tolerance has met the validity and reliability. Both of these measuring instruments are used to collect data on 112 adolescents at school X in Jakarta. This study want to research the relationship of spiritual well-being and tolerance for teenagers. Research data were analyzed by correlation. The results of data collection are then processed and analyzed with SPSS version 15.0 for Windows software.

\section{Result And Discussion}

Through the correlation test, it was found that there was a significant relationship between spiritual well-being and tolerance in adolescents in X Jakarta school $(\mathrm{r}=0.475 * *$, $\mathrm{p}$ $=0.000<0.01)$. What is the correlation of spiritual well-being with tolerance when viewed according to each dimension? The personal, communal, environmental and relationship with God dimensions of spiritual well-being have a significant correlation with the peace dimension of the tolerance attitude variable $(\mathrm{r}=0.207 *$ to $0.477 * *, \mathrm{p}=0.000-0.028$ ) Likewise, all dimensions of spiritual well-being have a significant correlation with the dimensions of awareness of tolerance ( $r=0.273 * *$ to $0.427 * *, p=0,000-0,004)$. Only the personal and transcendental / God dimensions of spiritual well-being that have a correlation with dimensions respect the differences of the tolerance variable $(\mathrm{r}=0.321 * *$ to $0.408 * *, \mathrm{p}=$ 0.000 - 0.001). While the other two dimensions (communal and environmental) of spiritual well-being do not correlate at all with the dimensions of respecting differences in tolerance. For more details, consider the following table.

Table 1. Test Correlation between dimensions of the variable spiritual well-being (SWB) with tolerance (ST)

\begin{tabular}{|c|c|c|}
\hline Variables Dimensions & Correlations Result & Significance \\
\hline Personal_SWB to peace_ST & $\mathrm{r}=0,393^{* *}, \mathrm{p}=0,000$ & significant relationship \\
\hline Communal_SWB to peace_ST & $\mathrm{r}=0,343^{*} *, \mathrm{p}=0,000$ & significant relationship \\
\hline Environ_SWB to peace_ST & $\mathrm{r}=0,207 *, \mathrm{p}=0,028$ & significant relationship \\
\hline God_SWB to peace_ST & $\mathrm{r}=0,477 * *, \mathrm{p}=0,000$ & significant relationship \\
\hline Personal_SWB to difference_ST & $\mathrm{r}=0,321 * *, \mathrm{p}=0,001$ & significant relationship \\
\hline Communal_SWB to difference_ST & $\mathrm{r}=0,170, \mathrm{p}=0,073$ & No relationship \\
\hline Environ_SWB to difference._ST & $\mathrm{r}=0,138, \mathrm{p}=0,147$ & No relationship \\
\hline God_SWB to difference_ST & $\mathrm{r}=0,408 * *, \mathrm{p}=0,000$ & significant relationship \\
\hline Personal_SWB to awareness_ST & $\mathrm{r}=0,427 * *, \mathrm{p}=0,000$ & significant relationship \\
\hline Communal_SWB to awareness_ST & $\mathrm{r}=0,273 * *, \mathrm{p}=0,004$ & significant relationship \\
\hline Environ_SWB to awareness_ST & $\mathrm{r}=0,285^{* *}, \mathrm{p}=0,002$ & significant relationship \\
\hline God_SWB to awareness_ST & $\mathrm{r}=0,403 * *, \mathrm{p}=0,000$ & significant relationship \\
\hline
\end{tabular}


This study shows that there is a significant relationship between spiritual well-being and tolerance for young people in school X in Jakarta. Spiritual well-being is an internal element of a person who contains a person's well-being related to his relationship with himself (personal), relations with others (communal), relations with the natural environment, and relations with transcendental things (God). This spiritual well-being correlates significantly with tolerance which has three dimensions, namely peace, respect for difference and awareness. It turns out that almost all dimensions of spiritual well-being are positively correlated with the three dimensions of tolerance, except that the communal and environmental dimensions of spiritual well-being do not correlate at all with the dimension of respecting differences in tolerance. So apparently people who have a harmonious relationship with the environment of the universe have nothing to do with the dimension of respecting differences in tolerance.

But rather a problem, why do people who have good relations with others (communal) have nothing to do with mutual respect for differences? The two dimensions should have a correlation. It can be that if someone is so intensive with someone else in his group, so that he becomes less respectful of other people outside his group. In general, the results of this study are in line with Walker (2011)[12] who saw a link between spiritual well-being and tolerance of Adventists in Yamaica. But what's interesting about this study is that the dimensions of the relationship with the transcendental (God) of spiritual well-being have the highest correlation score for the three dimensions (peace, respect for differences, and awareness) of the tolerance variable. Can this be said that talking about the spiritual well-being of people associates directly with transcendental problems? The weakness of this study is the number of subjects that are less numerous and have less varied subject backgrounds. It's good in the next study to do research on more subjects with different social backgrounds as well.

\section{Conclusion}

Based on the results of this study it can be concluded that there is a significant correlation between spiritual well-being and tolerance among young people in a school $\mathrm{X}$ in Jakarta. When viewed per dimension it appears that the dimensions of relations with transcendental things (God) have the highest correlation with all dimensions of tolerance. Only the communal and environmental dimensions of spiritual well-being do not correlate with the dimensions of respecting differences in the variable tolerance. The results of this study provide an explanation and affirmation of the importance of spiritual well-being in building tolerance among young people.

\section{Acknowledments}

This research is part of the 2019 Ristekdikti Grant. Thank you to Ristekdikti and the DPPM Universitas Tarumanagara Jakarta for providing funding so that this research can be carried out. 


\section{References}

[1] Gerintya, Scholastica, 2018, Benarkah Intoleransi antar Umat Beragama Meningkat (Is it true that Intolerance between Religious People Increases), in: https://tirto.id/benarkah-intoleransiantar-umat-beragama-meningkat-cEPz

[2] Supriyanto, Agus \& Wahyudi, Amien, 2017, Skala Karakter Toleransi: Konsep dan Operasional Aspek Kedamaian, Menghargai Perbedaan dan Kesadaran Individu (Scale of Character Tolerance: Concept and Operational Aspects of Peace, Respecting Differences and Individual Awareness), Jurnal Ilmiah Counsellia, vol. 7 no. 2, Nopember: 61-70.

[3] Fisher, J.W., 2010, Development and Application of a Spiritual Well-Being Questionaire called SHALOM. Religions 1, 105-121.

[4] Bufford, R.K., Paloutzian, R.F., Ellison, C.W.,1991, Norms for the Spiritual Well-Being Scale. Journal of Psychology and Theology 19 (1), 56-70.

[5] Fisher, J.W., Ng, D., 2017, Presenting a 4-Item Spiritual Well-Being Index (4-ISWBI). Religions 8,179 .

[6] Khisbiyah, Y., 2007, Menepis Prasangka, Memupuk Toleransi untuk Multikulturalisme: Dukungan dari Psikologi Sosial (Dispelling Prejudice, Cultivating Tolerance for Multiculturalism: Support from Social Psychology). Surakarta: PSB-PS UMS.

[7] Galtung, J., \& Fischer, D., 2013, Positive and negative peace, in: Johan Galtung, Springer Berlin Heidelberg, 173-178).

[8] Bahari, H. (editor), 2010, Toleransi Beragama Mahasiswa. Studi tentang Pengaruh Kepribadian, Keterlibatan Organisasi, Hasil Belajar Pendidikan Agama, dan Lingkungan Pendidikan terhadap Toleransi Mahasiswa Berbeda Agama pada 7 Perguruan Tinggi UmumNegeri. (Student Religious Tolerance. Study of Influence Personality, Organizational Involvement, Learning Outcomes of Religious Education, and Educational Environment for Student Tolerance in Different Religions at 7 Public Universities.) Jakarta: Badan Litbang dan Diklat Kementerian Agama.

[9] Santrock, J.W., 2003, Adolescence. McGraw Hill.

[10] Rumini, S., \& Sundari, S., 2004, Perkembangan Anak dan Remaja (Children and Adolescence Development). Jakarta: PT Rineka Cipta.

[11] Tillman, D., 2004, Pendidikan Nilai untuk Kaum Muda (terj. Risa Pranoto) (Value Education for Young People), Jakarta: Grasindo.

[12] Walker, M.D., 2011, "Religious Tolerance and its Relationship to Spiritual Maturity and Religious Orientation Among Seventh-day Adventists in Jamaica”. Dissertations.1523. http://digitalcommons.andrews.edu/dissertations/1523 